\title{
GERMAN CHURCH ARCHITECTURE
}

\author{
Boștenaru Dan Maria, ${ }^{1}$ Meilă Alexandra ${ }^{2}$ \\ 1, 2 'Ion Mincu' University of Architecture and Urban Planning, Bucharest \\ (ROMANIA) \\ maria.bostenaru-dan [at] alumni.uni-karlsruhe.de, secretarsefuauim [at] \\ uauim.ro
}

\begin{abstract}
This paper presents the heritage of Germans in Romania (Danube Swabians and Transylvanian Saxons) in relationship with the regions of emigration in the home country of Germany. Nowadays there are institutions dealing with the effects of immigration on art and architecture, including research institutions and museums, and the paper makes reference to these. Also, Italian research is interested in the province of Dacia and many conservation methods come from those lessons, while many of the buildings in the home country were inspired by Italian journeys. The heritage was subjected to disasters over time (earthquake, fire, war among others) and is facing abandonment today, for which reason conservation and management of these heritage buildings is important. This conservation includes also digital conservation, such as CAD virtual reconstruction and laser scanning. The confessional history has been different, with the Saxons arriving before the church Reformation and becoming protestant, while the Swabians arrived as part of the Counter-Reform of Emperor Maria Theresia of the Habsburgs. This, and the position of the dominant architecture programme for the respective periods of history of architecture determined the position of the churches of different confessions in the city. 2017500 years of Reformation were celebrated, which made the question of confession actual and the agreement today between Christians. Also, the basic professions of the immigrants influenced how the church architecture spread from urban to rural areas. Research methods included looking into both scientific literature and fiction dealing with the issue of German churches and the confessional history, research in the archives on urbanism issues, visit of the sites. Baden-Württemberg, the home of the Swabians, features even more important Baroque heritage after the emigration of the Danube Swabians, which opens the questions for incentives of the movement of population that time.
\end{abstract}

Keywords: Religious Architecture, Danube Swabians, Transylvanian Saxons, Baroque, Migration.

\section{INTRODUCTION}

We conducted a research on church buildings of German origin in Romania and in the places of origin of the German immigrants connected to the church reformation, which celebrated its 500th anniversary in 2017. This included the turn of Saxons to evangelic and the bringing of Danube Swabians in the course of the Counter Reformation of the Habsburgs under Maria Theresia. 


\section{\#3/2018 URBAN CHALLENGES}

The region of South-East Europe which historically was in the span of tensions of the Habsburg multi-ethnic empire as well as the Ottoman multi-ethnic empire is historically multi-ethnic. Multiculturalism which is today experienced through immigration of refugees in former national states such as Italy and Germany here exists historically and there are political solutions for this. This left the traces also on art and architecture and may be subject of research for different programmes related to emigration. In case of Transylvania this can be from Romania, German or Hungarian funding. 2009 the conference of the Foundation Transylvania Nostra on "Theoretical and Practical Issues on Built Heritage Conservation - Tusnad" had as topic "The Vernacular and the Multicultural Dialogue" [1]. As such, the heritage of the Germans who came to Transylvania for different reasons (the Saxons to protect the frontiers through founded cities, the Danube Swabians for confessional reasons and to revive agriculture after numerous falls by the Turks) is a testimony to this.

The most important method used was the site visit, to experience the heritage first hand. To this connects the photographic research of the urban ensemble, the architectural object and the details. The second method was the review of literature. Besides of scientific literature although fiction connected to churches was looked on. Scientific literature comes not only from Romanian, German and Hungarian space, but also from Italy, connected to both conception and conservation of this heritage. Apart of this some archives, including in Italy, were consulted.

\section{MARIA THERESIA AND THE BAROQUE}

The Danube Swabians were brought to Transylvania by emperor Maria Theresia about 300 years ago. If we were to see the spirituality of Maria Theresia, we visited in the anniversary year 2017 Kloster Neuburg near Vienna, a monastery of the Augustinians north-east of Vienna. The foundation was laid in the Middle Ages, but today's architecture is Baroque. The image of Maria Theresia is also depicted in the Danube Swabians museum in Ulm, Germany. The urban planning of Maria Theresia was to give importance to catholic church buildings in the course of counter reform. A good example is Timișoara in Romania [2].

Ulm is a city situated in Germany on the Oberschwäbische Barockstraße (the barock street of Upper Swabia [3]), a cultural route marked by various churches and monasteries from the time of the Baroque. The Danube Swabians left in that period, tired from wars before. But the region then enjoyed a development. In Timis and Sathmar Baroque developed afterwards as well, as it can be seen mainly in church architecture, but sometimes also in the architecture of houses. For this a task to be later developed is to look at the housing types in the village museum in Bad Schussenried, a locality housing also a baroque monastery with an impressive library, in the property of Staatliche Schlößer und Gärten. Another impressive landmark of the street is the basilica in Weingarten near Ravensburg, a place of pilgrimage to the blood Christy. The provenience of the vernacular architecture of the Danube Swabians is discussed, between being inspired by the neighbouring nations found here [4] and the places of provenience [5]. We did a 3D model of the vernacular housing in Sathmar [6]. Staatliche Schlößer und Gärten (State Castles and Gardens Baden-Württemberg) [7] is a public governmental institution 


\section{\#3/2018 URBAN CHALLENGES}

which administers castles, monasteries and gardens which belong to the state in Baden-Württemberg. Similar institutions exist in other German lands.

\section{THE NARRATIVE}

We look mainly at architecture, but the connection between architecture and literature is not to be neglected. As such, Ken Follett, a British bestseller author, was decorated for the promotion of architecture in his novels. Pillars of the Earth and World without End are writing on the construction of a church to monastery and the subsequent constructions in the city, being translated also in construction management games. It takes place before, in the time of Gothic.

Hermann Hesse, the Nobel laureate, wrote Narziß und Goldmund [8] to take place in the monastery of Maulbronn (as evangelical seminar building), also a monastery belonging to Staatliche Schlößer und Gärten. The monastery is one of the best kept north of Alps from its time. In Calw by Karlsruhe there is the birth house of Hermann Hesse, a half-timbered (Fachwerk) house and a museum to the author.

Similar to Maulbronn is the evangelical church and the ruin of the former monastery in Bad Herrenalb. Bad Herrenalb is one of the 3 resorts in the mountains of the Black Forest south of Karlsruhe, along with Bad Wildbad (close to Calw) and Baden Baden. The role of the ruin to the resort, which in 2017 housed the garden exhibition of the land, is to be researched. The other two resorts have also remarkable thermal bath buildings.

But also related to Romania, the play Vlaicu Vodă [9] tells about Catholicism in Walachia, by Alexandru Davila, introduction which determined the Saxons in Câmpulung to remain Catholics unlike the Saxons of Transsylvania and as such assimilated by the majority of the population. The Bărăția catholic church in Câmpulung was subject of laser scanning in the project ReSITUS along with the Negru Voda orthodox monastery in the same city [10], [11]. The Baratia church was restored to Communist time by Ștefan Balș, an architect who also studied at Accademia di Romania a Roma [12].

\section{THE TRANSYLVANIAN SAXON HERITAGE}

The Saxons came to Transylvania 800 years ago and hence their religious heritage is many times from a time of the Gothic. Since they had to withstand the numerous attacks of Turks and Mongols the churches developed as fortified. Apart of Câmpulung outside the Carpathian arch, the Saxons settled in the interior, and built mainly 7 fortresses, hence the German name Siebenbürgen.

A remarkable church is the Black church in Brasov, the largest Gothic church in Eastern Europe [12]. The church bears the name black from the 1689 fire after which it was restored during the time of the Reformation. This way the disaster is linked to a change in confession, and the interior space was changed in reconstruction to the evangelic needs of the Saxons.

In Sibiu, we see a similar urban planning in the Great Place with the Bruckenthal palace and the catholic church, the evangelic church remaining in the medieval pattern side to the Small Place as we mention to Maria Theresia. The Gothic church of the majoritarian Saxons is in the side, as we will see the catholic church 


\section{\#3/2018 URBAN CHALLENGES}

in Karlsruhe, while the catholic baroque church is opposite the Bruckenthal palace in the main place. Sibiu also features the current headquarters of the association of German evangelic church in Transilvania, in Neppendorf. Here a number of cultural activities take place. As such, architecture related, in September 2010 there was a conference on Bürger als Architekten ihrer Stadt (Citizens as architects of their city) [13] dealing with participative planning and since a number of years they are co-organiser of the conference series on Library and Information Science [14].

Similar place for cultural activities is the church in Dealu Frumos/Schönberg (cf. Figure 1) which is administered by the "Ion Mincu" University of Architecture and Urbanism [15] as study centre for vernacular architecture. Although a fortified church, it is not on the list of UNESCO protected churches. However, the change of function rendered it case study for the COST action TD1406 "Intelligent management of heritage buildings" [16].

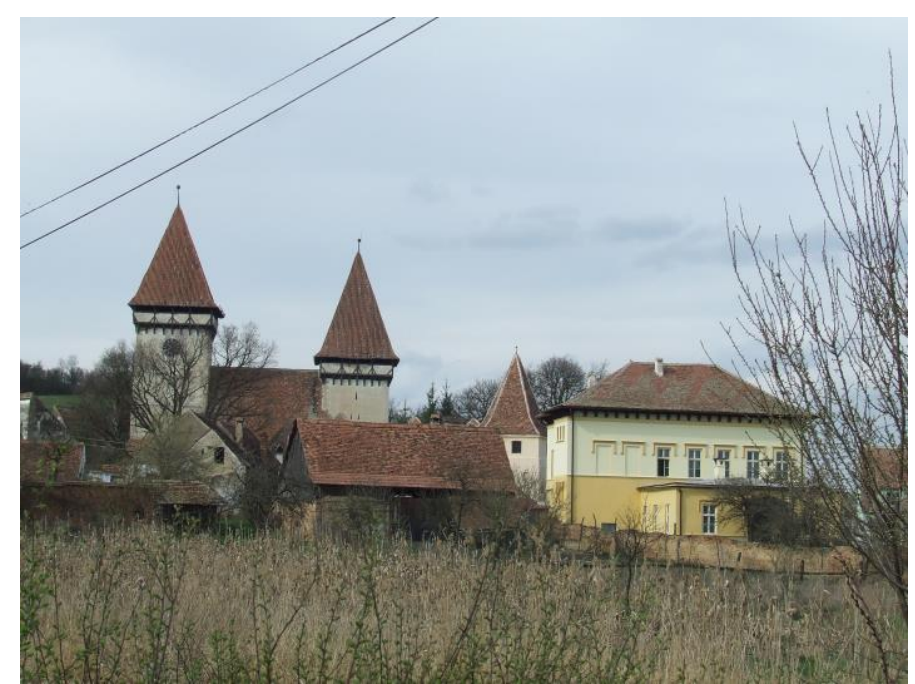

Figure 1: Religious Heritage of the Transylvanian Saxons. Church in Dealu Frumos/Schönberg

Source: Maria Boștenaru Dan (2014).

The first UNESCO protected church was the one in Biertan/Birthälm [17]. After that, another 6 joined. Biertan is close to Mediaș, another former Saxon city. One of the albums published on this heritage is [18].

From the new churches on UNESCO list, the one in Viscri/Deutschweißkirch caught the attention of Prince Charles and the Mihai Eminescu trust under his protection. It was subject of a number of restorations respecting the Saxon heritage in vernacular architecture. But Mihai Eminescu trust also restored the synagogue in Mediaș [19]. A photo of Viscri we did made it into the exhibition Germans in Romania organized by EuroFotoArt and displayed in Sibiu and in Austria, in Kärnten [20]. Other fortified churches in the region are Keisd and Prejmer.

Sighișoara/Schäßburg is another Saxons heritage on UNESCO list. Actually, the Danube Swabian Museum in Ulm hosts in spring 2018 an exhibition about Germans in Romania with catalogue [21], talking also about the approach to monuments 


\section{\#3/2018 URBAN CHALLENGES}

and restoration. The German institutions are involved in restoration, as the GTZ which had projects in Sibiu and Timișoara [22].

In Germany, there is a museum dedicated to the heritage of Transylvania in Gundelsheim am Neckar [23], which is a research institute of the University of Heidelberg.

In Bucharest, there is an evangelic church [24], and Queen Elisabeth of Romania, Princess of Wied, contributed to the interior decoration of the church, which was sadly lost during restoration.

\section{THE HERITAGE OF THE DANUBE SWABIANS}

To the Danube Swabians belong various stories, for example Josef Wohnhas [25].

Danube Swabians can be found in two locations in Romania: in Banat and in Sathmar. In Sathmar the Danube Swabians were brought by the count of Karolyi. 2012 there were 300 years since the begin of the immigration. The count of Karolyi was a mighty count, with numerous castles across Hungary, but the main headquarters in Carei, Romania. The wealth of the count was well above Budapester nobleman, and there is a Karolyi palace in Budapest as well, now the literature museum. In Carei the Károlyi count launched the most important Hungarian architect, that time young, Miklos Ybl. Young Miklos Ybl reconstructed damaged churches in the 1834 Érmellék earthquake, and maybe this after what he was launched as architect of the Károlyis. One of these important ones is the one in Căpleni/Kaplau by Carei [26] (Fig. 2), where also the Károlyis are buried. The main roman catholic church in Carei [27] is related as baroque architecture to the dome in Timișoara [2]. Carei is like Timișoara a multiethnic multiconfessional city, with also reformed church, orthodox church, synagogue. The reformed church in the village of Ciumesti/Schamagosch by Carei was present as restoration at the Architecture Biennale in 2014 [28]. The church in Foieni/Fienen was designed by a German architect from Würzburg, Joseph Bittheuser, who served the Karolyi count [29]. Timiș features two pilgrimage churches, Maria Radna and Maria Ciclova [2]. 


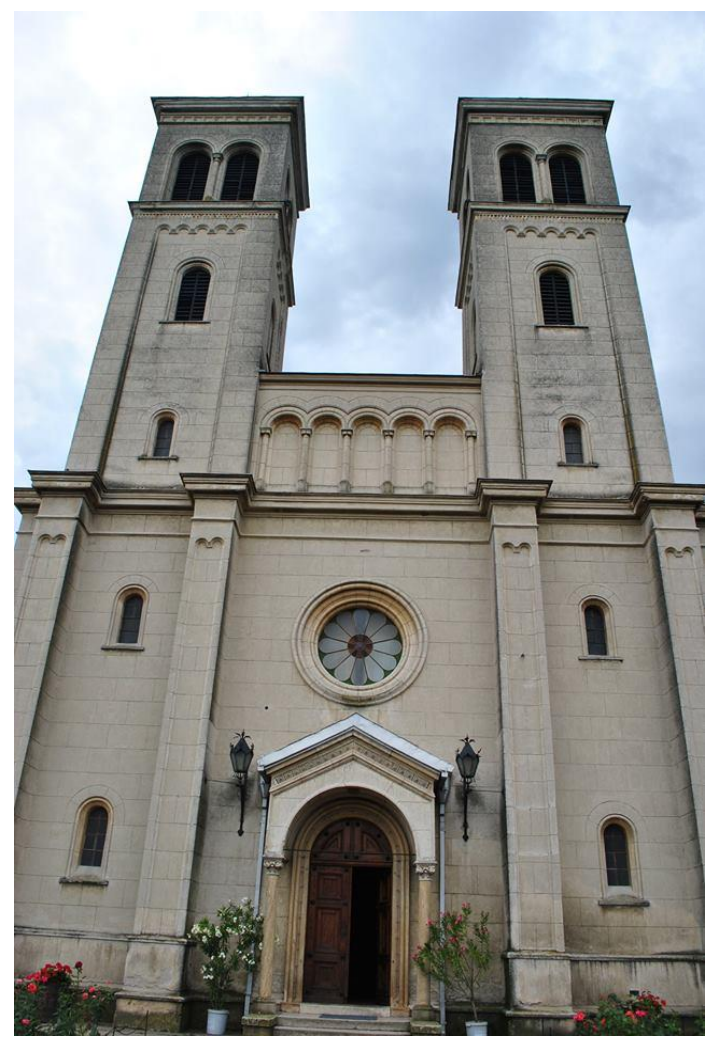

Figure 2: Religious heritage of the Danube Swabians: Church in Capleni, reconstructed by Ybl Miklos

Source: Maria Boștenaru Dan (2014).

The Hungarian conationals had not evangelic or catholic churches, but reformed ones. The association Transylvania Nostra organized an excursion to timber churches resembling the Saxon ones in Crasna/Kraszna and Șamșun/Szilágysámson (Zalău), the later with Baroque timber roof [30]. Like in Mediaș where the first woman architect of Transylvania (Erika Paulas [31]) built a hospital, in Cluj she built a seminar building to the reformed church in Farkas street. Also, Károly Kos, the architect inspired by vernacular architecture, built a reformed church in Cluj. But most notable reformed churches are those by Imre Makovecz [32]. In Cluj there is a reformed church, and in Timișoara a reformed collegium. Also, in Sfântu Gheorghe there is a reformed funerary chapel. However, in Miercurea Ciuc the church is catholic. Close to Miercurea Ciuc there is a pilgrimage place in Sumuleu Ciuc with an open altar for the mass of the masses also by Makovecz. These churches can be put in connection to those of Hungary, such as the reformed church in Siofok on the south Balaton shore, the ecumenic church in the central place of the reconstruction in Devecser, a place rebuilt after the chemical catastrophe of Ajka and the burial chapel in the cemetery of Farkasrét in Budapest. In Szazhalombatta by Budapest he built a catholic church, as well as the buildings of the Pázmány Péter catholic university by Budapest. For Budapest the church could not be built, but in 2014 there was an exhibition in the Academy of Arts founded by him displaying 3D models. Related to German heritage, when close to the Danube Swabians inhabited regions the architecture 


\section{\#3/2018 URBAN CHALLENGES}

was related, such as to Fachwerk in the Visegrad sports hall (1985), or the village hall in Kakasd (1986) close to Pécs/Fünfkirchen. The latter features a Swabian tower and a part resembling the Swabian house. The interior theatre room features a roof similar to that seen at the reformed church of Crasna. These churches also have important timber parts, such as the German built church in Érd by Budapest, also close to the Swabian place of Törökbálint/Großturwald, where Le Notre is organizing an Erasmus seminar [33]. Danube Swabians were namely represented on the territory of the Habsburg empire, being brought by Maria Teresia.

Apart of the Museum in Ulm [34], dedicated to Danube Swabians, there are a number of Danube Swabian houses across Germany, mainly in Baden Württemberg (Württemberg stays today for Swabians), the first one being in Sindelfingen by Stuttgart [35] which features a typical room, but where is also possible to do research on ancestry. For the Sathmar Swabians this is largely covered by [36]. In Tübingen there is a research institute [37] to this heritage, with library and photo library.

\section{BADEN WÜRTTEMBERG, THE HOME COUNTRY OF THE SWABIANS}

Back in Germany, in Baden Württemberg, few years after the begin of the emigration of Swabians new cities such as Karlsruhe were founded (1715). They were plan cities of the Baroque, although the architecture was Classicist by the architect Friedrich Weinbrenner [39]. The city offered facilities to those moving to the city to attract them, like freedom of taxes and encouragement of multiconfessionality. Although the count of Karlsruhe was from Durlach and evangelical, the neighbouring Baden Baden was catholic. The main catholic church was designed by Weinbrenner and is situated a little out of the main Via Triumphalis of the city. It is inspired by the church of Minerva in Assisi, Italy, where Weinbrenner went during his Rome stay [40]. The church was damaged during the World War II and got afterwards a new reinforced concrete cupola. However, from an urbanistic point of view it played an influence in the designs in the competition for the Baden library on the opposite side. Both Aldo Rossi [41] and the winning project of Ungers refer to the cupola in their designs. In 2017 out of respect for the Luther year at 500 years since reformation a statue of Luther was displayed in the church. We talked about this church as a case study in this journal [42]. The city of Karlsruhe, born in the time of the Baroque, was an absolutist city of the count, different of the Medieval founded cities of the Saxons. The evangelic church is situated on Via Triumphalis out of the castle. The exterior walls and columns resisted the bombing [43] but the interior was redone in reinforced concrete. Julian Hanschke is preparing a digital reconstruction which was partly shown during the 300 years anniversary [44]. Other notable evangelic churches in Karlsruhe are the church at Gottesauer Platz, a church in the style of National Romantic and as such related to that of Aladar Arkay in Budapest and of Alvar Aalto in Tampere, Finland. The architect Otto Bartning, who also enjoyed stay in Rome, designed 3 evangelic churches in Karlsruhe: Markus church on Yorck place (1934-1935), Church of Peace in Karlsruhe-Weiherfeld (1949), Thomas church in Karlsruhe-Daxlanden (1958-1960). The post-war period displayed the presence of another architect of church architecture in Karlsruhe. Ottokar Uhl, a 


\section{\#3/2018 URBAN CHALLENGES}

Viennese architect known for the pioneering participative planning [45], hence important for the sociology of architecture built a church in Karlsruhe Neureut. The theory of the architect was that churches shall be demontable after use, as also the montage church Siemensstreet in Vienna Floridsdorf (1962) shows.

Unlike in Romania, cemeteries in Germany are not confessional. The same Staatliche Schlösser und Gärten administers the burial chapel of the counts of Karlsruhe in the forest. In the main cemetery there is a burial chapel as well.

We were also involved in the practica to a monastery, the Monastery of Sf. Ioan in Bucharest (Bucureștii noi), featuring also timber elements as in the churches shown. Although the monastery was thought with a quadratic courtyard, given that not all necessary parcels could be bought, this did not happen.

Today Baden-Württemberg is even more connected to Romanian historical research through the heritage of the Romanian Royal House.

\section{DISCUSSION AND CONCLUSIONS}

2017 was the year to celebrate 500 years of reformation. There were 500 years since Martin Luther proclamed his thesises. It was an occasion for different celebrations in the city of Luther, including landscape architecture. Atelier Le Balto designed for Lutherstadt Eisleben and the garden show IBA Stadtumbau (urban regeneration) Sachsen-Anhalt in frame of the project "Lutherweg Eisleben" (the way of Luther in Eisleben, 2008). Before it obtained the 1st prize in a competition in 2007 [46] as presented at the conference on landscape 2016 in Karlsruhe [47].

The Saxons of Transylvania immigrated Catholic but became Evangelic, while the Danube Swabians were part of Counterreformation and were there to increase the Catholic population. This immigration history is reflected in the art and architecture of the immigrants as the article shows. The churches also changed with confession, from the middle age structure [48], [49].

Also the home regions from where immigration happened changed over time. The Saxons, who brought to Romania an urban civilisation [50], where warriors from that time Western Germany, and the heritage has little to do with the heritage in today's Germany, for example the Evangelical Frauenkirche in Dresden, restored recently after bombing. The Swabians on the opposite brought a rather agricultural village culture. The churched followed typisation in Banat [2], but were a different expression from the typical house. It is remarkable in Timiș Banat that at the time of the Baroque also the villages were planned as for example the city of Karlsruhe (the village of Șarlota/Charlottenburg, Frumușeni/Engelsdorf, Fântânele/Schönberg) in circular (the first) or rectangular shape. The colonists from Luxembourg came from the region of the historical Swabia, which included Alsace and Lorraine, in four villages of Timis Banat (Cenad/Tschanad, Biled/Billed, Peciul Nou, Dudeștii Noi/Neubeschenowa) [5]. The Swabian kingdom, from the same time as the Saxon one, encompassed the region over the origins of the Danube, including Alsace and norther Switzerland, with Strasbourg and lake Konstanz. In today's strategies of the Danube, it is a possible topic of research on how heritage travelled along the Danube. The Danube is today unification for a number of European countries with special community programmes. The theories of [4] and [5] relating the origin of rural housing of the Danube Swabians are 


\section{\#3/2018 URBAN CHALLENGES}

contradictory, while [4] sustains inspiration from local models of the multi-ethnic environment found in Romania, [5] sustains the models brought with them. For this it might be useful to study also the models of the Oberschwaben from where the migrants came, as in the village museum in Bad Schussenried [38]. In fact, [4] uses the research method of the village museums from Bucharest and Timișoara for typical colonist houses.

Some of the heritage of the Saxons and Swabians was affected by disasters, both natural (the 1834 Érmellék earthquake in Sathmar [51]) and man-made (the fire in Brasov, the war bombing in Karlsruhe). Churches as prominent heritage were particularly affected, due to their position in the tissue of the city and the monumental architecture. They are testimonies of changes in the history of the city. The emigration of the German inhabitants and the loss of religious attendants poses a new hazard in the $21^{\text {st }}$ century.

Finally, the church has been architectural program by excellence in the Middle Ages. This is when the Gothic fortified churches were raised. In the time of Counter Reform and Baroque, the castle was the one taking the most prominent position in absolutism, and the position of the church in the city in relationship with the city showed its importance. However, Austrian rules prescribed for planned villages in Banat to be in the centre [4].

\section{References}

[1] *** (2009), The Post Conference Volume TUȘNAD 2009 - The Vernacular and the Multicultural Dialogue, Utilitas, Cluj-Napoca.

[2] Volkmann, S. (2001), Die Architektur des 18. Jahrhunderts im Temescher Banat, Doctoral Dissertation, University of Heidelberg.

[3] *** Oberschwäbische Barockstraße. Available at: http://www.oberschwaebische-barockstrasse.de/ [19.03.2018].

[4] Panasiu, G. (2007), Habitatul rural ca expresie a multiculturalitatii in Banatul istoric românesc din timpul administrației austriece 1718-1867, Doctoral Dissertation, ,Ion Mincu' University of Architecture and Urban Planning, Bucharest.

[5] Pavlovici (Săbăilă), I.M. (2013), Identitatea modelelor din Luxemburg, Doctoral Dissertation, ,Ion Mincu' University of Architecture and Urban Planning, Bucharest.

[6] Boștenaru Dan, M. (2010), Vernacular and Modernist Housing in Germany and Romania. An Analysis of Vulnerability to Earthquakes, Cuvillier Verlag, Göttingen.

[7] *** Staatliche Schlößer und Gärten Baden-Württemberg. Available at: http://www.schloesser-und-gaerten.de/ [18.03.2018].

[8] Hesse, H. (1930), Narziß und Goldmund, S. Fischer, Berlin.

[9] Davila, A. (1902), Vlaicu Vodă.

[10] Nancu A. (2008), „ReSITUS* Metode şi tehnici avansate de conservare și reconstrucție digitală pentru patrimoniul cultural-istoric imobil", Buridava, 6/2008, pp. 215-224. 
[12] Institutul National al Patrimoniului (2016), Restauratori Români: Arhitectul Ștefan Balș (1902/1994). Available at: http://stefan-bals.ro/ [18.03.2018].

[13] Bálint Ziegler, Á. (2012), A Brassói evangélikus főtemplom (fekete templom) 18. századi újjáépítése. Felekezeti, politikai, rendi csoportidentitás kifejeződése egy újjászülető épületben, Doctoral Dissertation, ELTE, Budapest.

[14] Ziegler, Á. (2018), A Brassói Fekete templom - reformáció és renováció Felekezeti, városi, rendi csoportidentitás kifejeződése egy újjászülető épületben, Martin Opitz Kiadó, Budapest.

[15] Gherghel, C. (2010), "Gegen die Bauwut in Rumänien: "Stadtgestaltung Bürger als Architekten ihrer Stadt", Siebenbürgische Zeitung. Available at: http://www.siebenbuerger.de/zeitung/artikel/kultur/10395-gegen-die-bauwut-inrumaenien.html [19.03.2018].

[16] International Conference on Information Science and Information Literacy, Sibiu. Available at: Romaniahttp://bcu.ulbsibiu.ro/conference/ [19.03.2018].

[17] Nistor, S. (2010), Transilvania. Un patrimoniu în căutarea moștenitorilor săi, Arhitext, Bucharest.

[18] COST Action TD1406, "Intelligent Management of Heritage Buildings". Working Group 3, Questionnaire A3. Available at: http://td1406.eu/ [18.03.2018].

[19] German, K. (2004), „Die spätgotische Pfarrkirche in Birthälm in Siebenbürgen", in: von Wetter E. (ed.) Die Länder der Böhmischen Krone und ihre Nachbarn zur Zeit der Jagiellonenkönige (1471-1526) (Studia Jagellonica Lipsiensia, 2). Jan Thorbecke Verlag, Ostfildern, pp. 225-234.

[20] Ioan, A. and Derer, H. (2004), Biserici fortificate ale Sașilor din Transilvania/ Kirchenburgen der Sachsen in Siebenburgen/ Les églises fortifiées des minorites saxonnes de Transylvanie, NOI Media Print, Bucharest.

[21] Băldescu, I. and Coșnean, L. (2011), "Synagogues of the Austro-Hungarian Empire at the End of the XIX ${ }^{\text {th }}$ Century: The Case of Medias in Transylvania (Romania)", I beni culturali (Viterbo), anno XIX, n. 3.

[22] Toth, S. (Ed.) (2012), Die Rumäniendeutschen, Honterus, Sibiu.

[23] Demokratisches Forum der Deutschen in Rumänien and Botschaft der Bundesrepublik Deutschland in Bukarest (2014), Die deutsche Minderheit in Rumänien. Geschichte und Gegenwart im vereinten Europa, Honterus, Sibiu.

[24] Gabi, S. (2009), "Stadterneuerung in drei historischen Quartieren von Temeswar", in UAUIM-CSAU (Ed.), Regenerarea urbană în contextul transformării orașelor din România: situația actuală și perspective de dezvoltare/Urban Regeneration in the Framework of Romanian Cities Transformation: Present State and Development Trends, 'Ion Mincu' Publishing House, Bucharest, pp. 83-90.

[25] *** Siebenbürgen Institut online. Available at: http://www.siebenbuergeninstitut.de/ [18.03.2018].

[26] Zikeli, D. (2003), Vereinte Kraft wirkt Grosses. 150 Jahre evangelische Kirche A.B. in Bukarest, Blueprint Internațional, Bucharest. 
[27] Wohnhas, J. (2005), Petremr, Kharoulr, Finamr, Khaploanr, Schinalr, Khalmandr, Bescheneedr und andre G'schichta/Petri, Károlyi, Fényi, Kaplonyi, Csanálosi, Kálmándi, Csárdai és más történetek, Satu Mare.

[28] Budapest föváros levéltára: Ybl virtuális archivum. Available at: http://ybl.bparchiv.hu/temak/romai-katolikus-templom-es-mauzoleum-kaplony [18.03.2018].

[29] Bara, J. (2007), „A nagykárolyi Kalazanci Szent József piarista templom”, paper presented at X. Erdélyi Tudományos Diákköri Konferencia, Cluj-Napoca,

2007 may 26-27. Available at:
http://etdk.adatbank.transindex.ro/pdf/Bara\%20Julia\%202007\%20ETDK\%20n.pdf [18.03.2018].

[30] Emödi, T. (2014), Reabilitarea bisericii reformate din Ciumeşti, Bienala Națională de Arhitectură 2014. Available at: https://www.uarbna.ro/2014/proiecte/d/134/ [18.03.2018].

[31] Bara, J. (2016), „Joseph Bittheuser (1755-1828), a Károlyi család uradalmi építészének tevékenysége Szatmár megyében", in Orbán, J and Maros Megyei Múzeum (Eds.), Fundálók, pallérok, építészek Erdélyben, Erdélyi MúzeumEgyesület, Târgu Mureș, Cluj, pp. 53-90.

[32] Bostenaru Dan, M. (2011), Profil: Imre Makovecz, Arhitectura, 5/2011, p. 82-85.

[33] http://www.transylvaniatrust.ro/index.php/hu/programok/erdelyi-falkepekes-kazettas-mennyezetek-allagvizsgalata-es-vedelme/ [19.03.2018].

[34] Transsylvania Nostra (2012), Șarpante istorice din Transilvania. Available at: http://www.transsylvanianostra.eu/roofs/index.php?l=ro\&a=list\&o=Szil\%C3\%A1gy \%20megye\%20(SJ) [19.03.2018].

[35] Mészáros, M. (2013), "'...haladásunk legújabb tanusítója: az asszony építész." Magyar női építészek a múlt századelőn/ "...the latest proof of our progress is that women can be architects." Hungarian Women Architects at the Turn of the Last Century", in Kovács, Zs. and Orbán, J. (Eds.), Táguló horizont. Tanulmányok a fiatal múvészettörténészek marosvásárhelyi konferenciájának előadásaiból, Erdélyi Múzeum Egyesület - Maros Megyei Múzeum - Entz Géza Müvelődéstörténeti Alapítvány, Târgu-Mureș - Cluj, pp. 187-197.

[36] *** LED workshop in Törökbálint. Available at: https://ledwiki.hfwu.de/index.php?title=LED_Workshop_T\%C3\%B6r\%C3\%B6kbali nt_2018 [18.03.2018].

[37] *** Donauschwäbisches Zentralmuseum Ulm. Available at: http://www.dzmmuseum.de/ [18.03.2018].

[38] *** Haus der Donauschwaben Sindelfingen. Available at: http://www.hausdonauschwaben.de/wordpress/ [18.03.2018].

[39] Vonhaz, S. (1987), Die deutsche Ansiedlung in Komitat Sathmar, own publishing, Laupheim.

[40] Institut für Donauschwäbische Geschichte und Landeskunde, Tübingen. Available at: http://idglbw.de/en [18.03.2018]. 


\section{\#3/2018 URBAN CHALLENGES}

[41] *** Museumsdorf Kürnbach. Available at: http://www.museumsdorfkuernbach.de/ [18.03.2018].

[42] Städtische Gallerie Karlsruhe, SAAI (2015), ,Friedrich Weinbrenner 17661826 Architektur und Städtebau des Klassizismus', Michael Imhof Verlag, Petersberg.

[43] Schumann, U. M. and Bräunche, E. O. (Eds.) (2008), Friedrich Weinbrenners Weg nach Rom: Bauten, Bilder und Begegnungen, Lindemanns Bibliothek, InfoVerlag, Karlsruhe.

[44] Aldo Rossi Fund, Archive research at MAXXI, Rome, 2016.

[45] Boștenaru Dan, M., Dill, A. and Mihăilă, M. (2017), Integration of Reused and Retrofitted Buildings in Architectural-Cultural Surroundings in South-West Germany, JULP, 2, pp. 1-11.

[46] Werner, J. and Bauer, E. (1995), Die 40er Jahre: Ein Karlsruher Jahrzehnt in Bildern, Braun, Karlsruhe.

[47] Hanschke, J. (2018), Forschungsprojekt: Karlsruhe um 1820. Virtuelle Rekonstruktion des klassizistischen Stadtbildes. Available at: http://bg.ikb.kit.edu/521.php [18.03.2018].

[48] Leichtle, B. (1994), Partizipatives Bau-Planen. Möglichkeiten kooperativen Handelns im Planungsprozeß am Beispiel zweier Wohnprojekte, Doctoral Dissertation, University of Karlsruhe.

[49] le balto (2008), Ohrenweide. Available at: https://lebalto.de/2008/12/ohrenweide-2/ [18.03.2018].

[50] Florescu, T., Boștenaru Dan, M. and Dill, A. (2018), "Landscape - Concepts of Modernism and the Current practice", Urbanism. Architecture. Constructions, 9, 3, pp. 239-246.

[51] Machat, C. (1985) „Auswirkungen der Reformation auf die Ausstattung siebenbürgischer Kirchen", in Weber, G. and Weber, R. (Eds.), Luther und Siebenbürgen. Ausstrahlungen von Reformation und Humanismus nach Südosteuropa, Böhlau Verlag, Köln, pp. 309-326.

[52] German, K. (2008), "Sakramentshäuser und Sakramentsnischen in evangelischen Kirchen Augsburgischen Bekenntnisses in Siebenbürgen", in Wetter E. Formierungen des konfessionellen Raumes in Ostmitteleuropa, Franz Steiner Verlag, Stuttgart, pp. 125-132.

[53] Băldescu, I. (2005), Transilvania medievale. Le città fondate di Sibiu, Bistrița, Brașov, Cluj, Bonsignori, Roma.

[54] Zsíros T. (1983), "The Érmellék Earthquake of 1834", Acta Geodaetica et Geophysica Hungarica, 18, pp. 129-134.

\section{Article distributed under a Creative Commons Attribution- NonCommercial-NoDerivatives 4.0 International License (CC BY-NC-ND).}

Received: March 20, 2018

Accepted: April 20, 2018. 